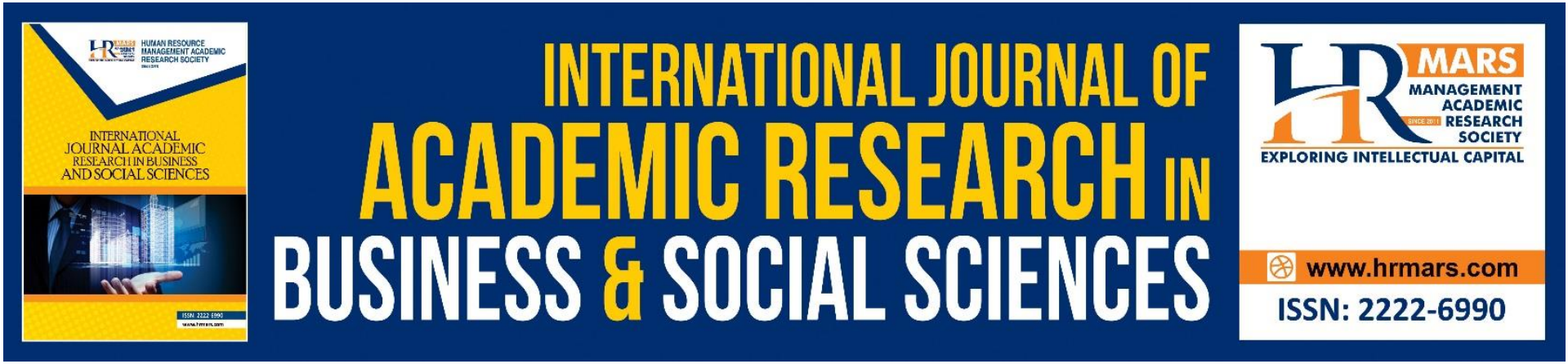

\title{
A Historical Appraisal of Ethics and Civilization in Malaysia from Pre-Colonial to Post-Colonial Era
}

Dayang Nurhazieqa Hamzani, Amini Amir Abdullah, Mohd. Daud Awang, Mohammad Nidzam Abdul Kadir \& Ahmad Faathin Mohd. Fadzil

To Link this Article: http://dx.doi.org/10.6007/IJARBSS/v11-i12/11785

DOI:10.6007/IJARBSS/v11-i12/11785

Received: 18 October 2021, Revised: 21 November 2021, Accepted: 30 November 2021

Published Online: 17 December 2021

In-Text Citation: (Hamzani et al., 2021)

To Cite this Article: Hamzani, D. N., Abdullah, A. A., Awang, M. D., Kadir, M. N. A., \& Fadzil, A. F. M. (2021). A Historical Appraisal of Ethics and Civilization in Malaysia from Pre-Colonial to Post-Colonial Era. International Journal of Academic Research in Business and Social Sciences, 11(12), 382-391.

Copyright: @ 2021 The Author(s)

Published by Human Resource Management Academic Research Society (www.hrmars.com)

This article is published under the Creative Commons Attribution (CC BY 4.0) license. Anyone may reproduce, distribute, translate and create derivative works of this article (for both commercial and non0-commercial purposes), subject to full attribution to the original publication and authors. The full terms of this license may be seen at: http://creativecommons.org/licences/by/4.0/legalcode

Vol. 11, No. 12, 2021, Pg. $382-391$

Full Terms \& Conditions of access and use can be found at http://hrmars.com/index.php/pages/detail/publication-ethics 


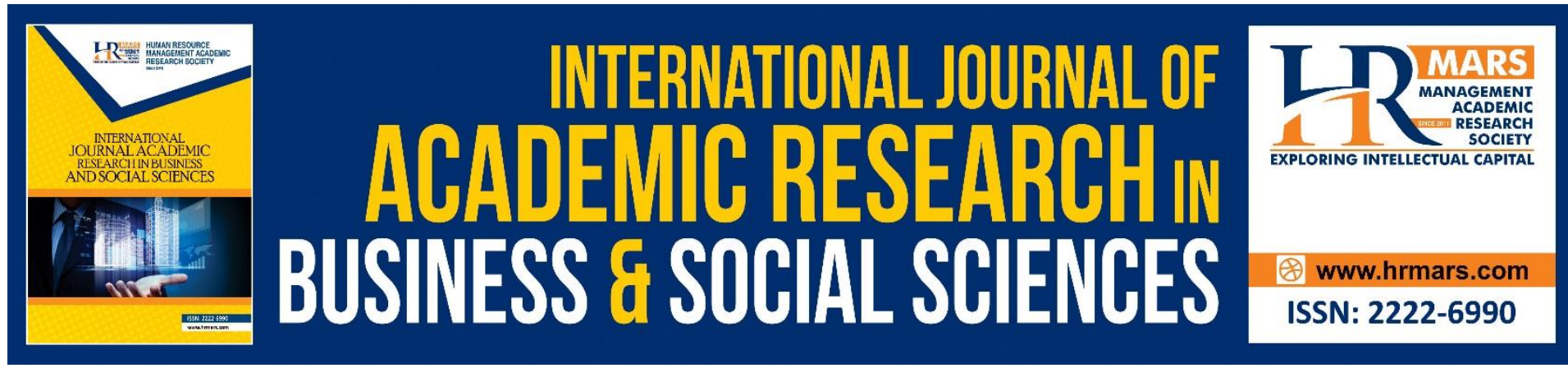

\title{
A Historical Appraisal of Ethics and Civilization in Malaysia from Pre-Colonial to Post-Colonial Era
}

\author{
Dayang Nurhazieqa Hamzani, Amini Amir Abdullah, Mohd. \\ Daud Awang, Mohammad Nidzam Abdul Kadir \& Ahmad \\ Faathin Mohd. Fadzil \\ Department of Government and Civilization Studies, Faculty of Human Ecology, \\ Universiti Putra Malaysia. 43400 Serdang, Selangor. \\ Email: nurhazieqa.hamzani@upm.edu.my
}

\begin{abstract}
This paper discusses the development of ethics and civilization with regards to Malaysia's history from its pre-colonial to post-colonial times. This paper analyses the meaning of ethics in Ancient Greek and its relationship to civilization and how ethical framework has changed throughout particular civilizations. It also discusses how the religious ethical framework as well as local culture and customs in Malaysia were affected when Western modernity was introduced to this region. It is argued that both the Hindu-Buddhist period and the Muslim sultanates period have a similarity in their ethical framework in that both frameworks are informed by a belief in the divine, much like the Homeric period in Ancient Greece. On the discussion on the colonial period, this paper emphasizes and draws distinctions between the Portuguese, the Dutch and the British taking into consideration the main events that had happened in Europe between the Portuguese' conquest of Malacca in 1511 and the British colonization in Malaya in 1824. Finally, this paper discusses on what this means to postcolonial Malaysia and the challenges it brings to the ethical discussion in Malaysia as well suggestions for possible meeting points to counter these challenges.
\end{abstract}

Keywords: Ethics, Civilization, Pre-colonial, Post-colonial, Malaysia

\section{Introduction}

Civilization, according to Will Durant, is a social order that promotes cultural creation and it has four elements that are important for a civilization; economic provision, political organization, moral traditions and the tradition of knowledge and the arts (Durant, 1963). AlAttas defines tamaddun, the Arabic term that correlates to civilization, as to do with refinement in social culture of the people and closely related to the Arabic term for city, madinah, which has to do with a well-governed life of societal law and order and justice and authority (al-Attas, 1978). An important element of civilization is the human element, which is the agent that pursues civilized living and creates cultural arts and the tradition of knowledge. The political aspect is also stressed by both thinkers, and to this dimension is added the understanding of justice. A civilized living and the development of civilization is 
then very closely linked with the understanding of morality and justice for the sake of law and order (Durant, 1968, p. 38).

Underlying this political and moral dimension of a civilization is ethics. Ethics is a moral principle or framework that acts as a guidance so that a person can act in a right or good behaviour. Moral is defined as pertaining to a distinction between good and evil, right or wrong, in relations to actions, volitions or character of responsible beings (Oxford English Dictionary, 1989). There are few keywords here that require further definition, such as good, evil, right and wrong. However, their definitions cannot be determined unless we know which framework we use, as different moral framework would define what is evil and what is good differently. For example, what is evil to a Hindu person from $4^{\text {th }}$ century BC in Kedah Tua would be different to what evil is to a $21^{\text {st }}$ century climate activist from modern Kedah. We could guess that evil for the former would take on a more mystical or metaphysical connotations but for the latter, evil would probably take on a more political/economical bent in a climate justice situation. While we would have no problem in agreeing that both constitute evil (the metaphysical and the political connotations), but what this shows is a repeating pattern when we compare how moral framework is viewed by those in the ancient, and then the medieval period to those of modern times. This transformation from a metaphysical-ethical framework to an ethics devoid of metaphysics reflects the change in the understanding of concepts related to ethics over time. Alasdair Macintyre, the ScottishAmerican moral philosopher, related this change to a change in moral framework. According to him,

\begin{abstract}
"At a certain period, when moral questions were asked, it became clear that the meaning of some of the key words involved in the framing of those questions was no longer clear and unambiguous. Social changes had not only made certain types of conduct, once socially accepted, problematic, but had also rendered problematic the concepts which had defined the moral framework of an earlier world." (Macintyre, 2002, p. 5)
\end{abstract}

These 'social changes' happened in any society or civilization over time as the civilization expands its territory or opens its borders to receive diverse nations. Underlying this shift is also a change in the understanding of underlying beliefs and principles that makeup a certain society's worldview or framework. It is normal for the society's beliefs to change over time as the result of conversion to or adoption of a new worldview (Durant, 1968, p. 39) and we have seen this in the states that make up the Malay Archipelago in history.

This is the relevance of understanding the different times that any civilization's experiences so that we have a better appreciation of its ethical principles, thus the paper seeks to elaborate the question of ethics and civilization with an emphasis on history. The question of what is the ethical framework in modern Malaysia is interesting because of its history admits of diverse religious and moral traditions beginning from the precolonial times with its HinduBuddhist and Islamic influences; during colonial times with the introduction of Western ethical framework by the colonial overlords; and finally, today in the post-colonial era with the added influence from participating in a globalized world and having a multicultural demographic. Like all multicultural nations, the challenge has always been about thinking of the ideal standard to inform practices and behaviours; be it in education, administration, 
economy or cultural outlook. Therefore, in discussing ethics and civilization in Malaysia, it takes into consideration the different religious and ethical forces that have been at play in its history.

Fortunately, modern-day Malaysia is not the only place where we see evolution of ethical framework. The birthplace of Western philosophy, Ancient Greek, had also dealt with a shift in their ethical framework due to encounters with different cultures and tradition. The first section of this article will revisit the origin of ethics as understood in Western philosophy, as a way to understand better the link between ethics and civilization, as ethical framework changes along with civilization encounters. The next section gives a brief overview of the precolonial states and empires in the Southeast Asian region as far as it is relevant to the history of Malaysia, as well as an overview of the religions practiced during the time. In the third section, a brief history of ethics in the West and how this affects colonial Malaysia will be given. This serves also as a discussion on ethical framework introduced to this country during the colonial era. Finally, a discussion on the challenges on discussing ethics in Malaysia and its possible meeting points will be attempted in the fourth section.

\section{Section 1: A Brief Overview of the History of Ethics in the Greek Philosophy}

The term ethics and the understanding of it in relation to moral virtues originated in the Ancient Greek civilization, so it is important for us to see what ethics is to the Ancient Greeks. In Ancient Greek period, circa 500 BC, ethical questions begin with the question of what is good and the ancient Greeks already had a concept called agathos (áy $\alpha \theta$ òc) which was borne out of a hierarchically-structured Greek society. In such a society, each members of the society occupy a fixed role; the ruling class to govern the city-state, judges to adjudicate grievances, soldiers to defend the city-state and slaves who formed the backbone of its economy (Scheidel, 2008).

Each of this role has its attendant ideal virtues that will make the ones who occupy this role be able to truly serve his or her function. The ruler has to be wise, the judge has to be just and the soldiers must be courageous. Therefore, agathos for a king would mean wise while for the soldier, his agathos would be to be brave and skillful in war. Agathos, although often translated into English as 'good', in the moral framework of the ancient Greeks, is a quality which resides in each of those who played a role in society (Adkins, 1972, pp. 11-12). The one

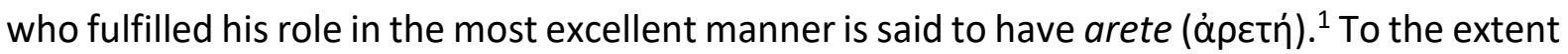
that each society's moral framework is upheld by an authoritative guideline, the Greeks have the Homeric epics which presented the ideals for what is the agathos for each roles. Homeric epics were influential in shaping the mores of ancient Greek society and its authoritative 'voice' came from the association with the divine. Its epic heroes are often of divine parentage and understood by the Greeks as being more virtuous than the common man. The ancient Greek society maintained its moral code by heavy emphasis on honour and shame. Thus, the ancient Greek society is one in which awareness of the gods and divine punishment exist and this metaphysical framework forms its ethical framework.

${ }^{1}$ Arete is a noun, and most often translated to as virtue whereas agathos is used as an adjective. 
To define ethics for the Ancient Greek is not enough to say what is good and what is bad; one would need to describe and situate how good and bad is judged in this society. Hubris (úßpıs) is the term used to denote a practice which goes against the moral order of the universe, and its practice will invite the wrath of the gods (Macintyre, 2002, p. 10). Notice that the current usage of hubris in modern English means excessive pride or self-confidence, having no connotation to metaphysics at all, e.g. no understanding of transgressing any moral order of the universe. In other words, it is a completely secular concept. The shift in understanding such ethical concepts and terms in a more secularized manner is something that can be noted as we move from an ancient or classical society to a modern one.

Plato would continue Greek ethical discussion in terms of arete, where he formulated the four cardinal virtues that are needed in men; courage, wisdom, temperance and justice. It is interesting to note here that Plato is responding to moral relativism brought about by the Sophists which argued, among others, that goodness or justice is relative to the customs of the city-states. The Greek city-states of the fifth century BC where Sophists roamed and taught ethics and politics to eager and ambitious youths have changed somewhat from those of Homeric time and the sophists were free to question accepted norms and proposed a subjectivist and relativist account of moral values (Barney, 2012). This was brought about by the encounter of the Greeks with other cultures and most of the Pre-Socratic philosophers are known to wander from cities to cities and incorporate accounts about other cultures in their thoughts (Feyerabend, 1987). Ethics, then, in Plato's time, seemed to have been reducing the wider influence of the Homeric understanding of honour, shame and the gods, since it was the gods and the commonly accepted virtues which the Sophists are now challenging.

Plato's ethics, contrary to the Sophists, affirm objective truth and that goodness and other virtues are absolute and objective. Aristotle, his student, retained the four cardinal virtues of Plato and affirmed an objective telos (objective or end) to each virtues, with the highest telos residing in the divine. What is similar in them to the Homeric moral framework is that that they all tie the question of what is right or wrong to that of the divine, or metaphysical. This, in brief, is the development of ethics in ancient Greece.

To conclude this part, we note that ethical framework of the Greek is closely linked to the divine or a metaphysical background which admits of a higher being. The second point that is also important to keep in mind is the challenge of relativism by the Sophists on Greek ethical frameworks due to civilizational encounters. It will be argued that one way to appraise the development of ethics in Malaysia is by comparing it to the Ancient Greek because both centers their ethical framework on the divine and both encounters other civilization that effect changes onto their ethical framework.

\section{Section 2: Ethics and Civilization in Pre-Colonial Malaysia}

Malaysia is unique in that while being a collection of Muslim sultanates before it was first colonized by the Portuguese in 1511, it was a Hindu-Buddhist thalassocracy for over 600 years before Islam became a major religion. Therefore, a brief look on the Hindu-Buddhist ethical framework and its customs whose traces can still be seen in contemporary times will be undertaken in this section, followed by that of Islam during the period of Malacca Sultanate. 
In prehistoric times, the first instance of human settlements in Malaysia can be found in Niah caves in Sarawak, with human remains dated to be as old as 40,000 years old, which puts this as belonging to the Paleolithic age or the Early Stone Age. Lenggong Valley in Perak was the site of the earliest known modern human settlement in Malaysia, with the discovery of Perak Man, dated to be 10,000 years ago from Gua Gunung Runtuh (Chia \& Majid, 2002). Among the early major states or empires in the Southeast Asian region that dates back to $1^{\text {st }}$ century $A D$ is Funan Empire, an ancient Hindu empire in present-day Cambodia, which had active trade relations with China and India (Ramli et al., 2014, p. 89). At its peak, around $3^{\text {rd }}$ century $A D$, its territory stretched southward to present-day north Malaysia and westward to Burma (p. 92). Funan Empire's trade activities galvanized trades within the Malay archipelago and there were numerous entrepôt established in the Malay archipelago whose function is to be the gathering points for goods from interior as well as goods from India. These entrepôt were not governed under one major empire but formed their own smaller states which existed alongside Funan, and for some states, they became Funan's vassal states (pp. 88,90). These smaller states include Kedah Tua, Langkasuka, Pan-Pan, P'u-lo-Chung, Kiu-Li, Chih-Tu, and Lo Yueh, among others. Kedah Tua's location is in Lembah Bujang, Kedah, and its state lasted from $2^{\text {nd }}$ century $A D$ to $14^{\text {th }}$ century $A D$. Indian literary sources such as Tamil poetry during the Sanggam period showed close relations between Kedah Tua and South India (Khaw, Zainun, \& Saidin, 2017, p. 13). Kiu-li's location is near present-day Kuantan in Pahang and is thought to be the 'Koli' which was mentioned by Ptolemy, a Greek astronomer and geographer from $1^{\text {st }}$ century AD (Ramli et al., 2014, p. 98).

Funan Empire lasted until $6^{\text {th }}$ century $A D$ and was replaced by the Srivijaya empire as the major political and economic power in Malay Archipelago from the $7^{\text {th }}$ to 13 th century AD. Like Funan, this empire too is an Indianized empire with Buddhist influences and was sustained by the same trade economy of Funan, before being replaced by the Majapahit empire in the $13^{\text {th }}$ century. Majapahit would be the last major Hindu kingdom in the Malay Archipelago and according to the Nagarakretagama, which is a eulogy to the $14^{\text {th }}$ century Majapahit's king Hayam Wuruk, Majapahit's dependencies included Pahang, Ujong Medini (Johor), Langkasuka, Kelantan, Trengganu, Muar, Tumasik (or Singapore), Sang Yang Ujong (Sungai Ujong), Klang, Kedah and Jerai (Winstedt, 1935, p. 30). Its hegemony would be replaced by the growing presence of Islam in the region, which started the age of Muslim Sultanate states, with the increased importance of the kingdom of Malayu in Sumatera.

The existence of these Hindu-Buddhist states in the Malay Archipelago managed to spread the influence of both religions and Indian culture in the region. Mythical origins were attributed to Malay rulers to give them legitimacy in the eyes of the subjects and Sanskrit script and language began to be used not only for religious rituals but was also used in literature (Rahman \& Ahmad, 2017, p. 128). Al-Attas noted that the aspects of Hindu cultures that were assimilated by local Malays were more towards the literary aspect which includes epics, myths, and romance to the neglect of the more philosophical aspect of Hindu culture. This observation of his was based on the many literary manuscripts in circulation and existence compared to only one single copy of Nagarakretagama which elaborated a more rationalistic aspect (al-Attas, Islam dalam Sejarah dan Kebudayaan Melayu , 1972, p. 14).

Despite this, it is undeniable that Indian influence was pervasive in the culture of the local Malays even at the village level. Aspects of Hindu religion were easily adapted along with local animistic beliefs while Hindu epic like the Ramayana played a significant part in the culture 
of the local Malays (Andaya \& Andaya, 1982, p. 15). Modern Malay words retain many similarities with Sanskrit due to lexical borrowing such as the word kerana, gajah, rasa, warna, duka, dewa to cite a few. Srivijaya was also a place for Chinese Buddhist pilgrims to rest and as a transit point on their way to study Buddhism in Nalanda, India. According to the Buddhist pilgrim, I-Ching, who spent six months in Srivijaya to learn Sanskrit grammar, Srivijaya is the place for Chinese Buddhist pilgrims to learn the proper rules on Buddhism as a preparation for a deeper study in India (Coedès, 1975, p. 82). I-Ching also mentioned Srivijaya as having a thousand Buddhist monks who studied Buddhism and practiced its rituals and ceremonies just as they were practiced in India (p. 81). However, the level of its observance by the local laity is uncertain, and it has been suggested that Buddhism may only be practiced by the monks and not the laity due to the non-missionary nature of Buddhism (al-Attas, Islam dalam Sejarah dan Kebudayaan Melayu , 1972, p. 15). Regardless of this, Srivijaya was known to be a place where Atisha, the $11^{\text {th }}$ century reformer of Buddhism in Tibet, studied for eleven years with Dharmakirti (p. 15). Locals believed in the concept of Dewa-Raja and other mythical elements associated with the monarchy (such as origins, powers and etc) just as other Indianized cultures. From this brief overview of the HinduBuddhist period of the Malay Archipelago, it can be inferred that the ethical framework was not divorced from an underlying metaphysical beliefs of the gods, deities and mythical beings, reinforced by model figures who embodied noble virtues such as those found in the epics, making it not much different from the times of the Homeric epics of Ancient Greek.

The Malacca Sultanate was founded in 1400, although an earlier date of 1292 to the presence of a Malay state near Malacca is also possible according to Chinese sources (Winstedt, 1935, p. 37). Malay states in Sumatera include Pasai, Perlak and Jambi sultanates where Islamic culture and ethics are observed by the rulers themselves. The $14^{\text {th }}$ century North African traveler, Ibn Batuttah, in his writings talked of his stay with a king of Sumatra, al-Malik alZahir, who he described as "one of the noblest and most generous of kings." (MackintoshSmith, 2002, p. 256) Malacca Sultanate then was quite fortunate that when it was founded, Muslim states and Islam were already in ascendancy, providing a network of friendly states with similar goals and practices to which it could build relations with.

Due to the geography of the area, Malacca proves to be a preferred choice for transit and trade in the region. The fact that Malacca Sultanate was able to thrive in a region crowded with other, more established powers is an impressive feat and a testament to the wisdom and courage of its leaders and people. Malacca allied itself early on with China as a form of protection from Ayudhya (a Siamese kingdom) in the north and Majapahit in the South. This stability along with its location made it able to attract traders and became the main trading emporium of the Archipelago. Spices from this region were highly sought after and the high economic value invested in the spice trade was what attracted Portugal's interest, which then sought to monopolize this spice trade (Bakar, 2020, p. 9). The golden age of Malacca Sultanate ended with the invasion of Malacca by the Portuguese in 1511.

On the heights of Malacca Sultanate's glory days, due to its status as an important trading port, the city acquired a multi-cultural and cosmopolitan outlook. The arrival of the Europeans did not faze local Malaccans as they were already used to different ethnicities living among them such as the Chinese, the Gujeratis, the Bengalis, the Arabs, the Persians, and those from 
the different Southeast Asian states in the region, as reflected by this account by a Portuguese traveler, Tomi Pires.

There is a Xambandar (Shahbandar) for the Gujeratis, the most important of all. There is a Xambandar for the Bunuaqujlin, Bengales, Pegus, and Pase, there is Xambandar for the Javanese, Molluccans, Banda, Palembang, Tanjompura and Lacoes there is Xambandar for the Chinese, Leques, Chancheo and Champa. Each man applies to [the Xambandar] of his nation when he comes to Malacca with his merchandise or message (Abdullah \& Fathi, 2021, p. 168).

Malacca had an organised administration system to oversee the many different traders at its port and city and traders have a specific shahbandar or harbor master whose tasks include to oversee trade activities at the ports, collect taxes and manage business licenses (p. 168). A total of 84 languages were spoken in Malacca, although Malay remains its lingua franca, reflecting not only its cosmopolitanism, but the openness and tolerance practiced by the Sultanate (Abdullah \& Fathi, 2021, p. 168). As for the wealth of the sultanate, when it was sacked by the Portuguese in 1511, the sheer amount of wealth that the city owned awed Alfonso de Albuquerque himself who said that he had never laid his eyes on this much treasure anywhere else and declared Malacca's wealth as the earth's richest treasure (Merican, 2020, p. 44). ${ }^{2}$

Malacca Sultanate was not only important for the region's economy, it was also responsible for advancing the spread of Islam in the Archipelago, following the steps of earlier Muslim sultanates in the region. Arab teachers of Islam used Malacca as the launching pad of its Islamising activities and it was due to the relations with Malacca that Brunei's rulers embraced Islam (Majul, 2010, p. 35). Al-Attas credits Islam as bringing forth much rational and intellectual discussion among the local Malays as Muslim works of high intellectual values can be found that dealt with the topic of cosmology, ontology, and psychology like that found in tasawwuf works (al-Attas, 1972, pp. 20-21). Encounter with Islam also opened the Malay intellectual discourse beyond Hindu-Buddhist milieu to also include intellectual riches from the Greeks such as Plotinus, Plato and Aristotle via the works of the mutakallimin and the logicians (p.21). In the rulers' courts and among the local Malays, there is a shift from a focus on arts and literature into a more rational discourse.

The colonization of Malacca in 1511 did not stop the tide of Islamisation in the archipelago as the center of religious learning shifted to other Malay sultanates. The highly philosophical discourses are not only limited to the royal courts since only a few of these works were specifically written for the royal courts and the manuscripts were also in numerous copies (alAttas, 1969, p. 6). The Hukum Kanun Melaka, a legal constitution used in Malacca starting 1424, shows aspects of Islamic rulings and Malay adat or customs that were adapted according to Islamic law and used both the Quran and Sunnah as its foundation (Husain, Ngah, $\&$ Din, 2018, p. 62). This shows that the ethical framework practiced in Malacca Sultanate

\footnotetext{
${ }^{2}$ According to Tomi Pires, he estimated that in 1510, Malacca's trade was worth 2.4 million cruzados, which was an impressive amount when put in comparison with one of the richest ports in Europe, which is Seville, whose imported goods was worth four million cruzados at the end of the sixteenth century (Andaya \& Andaya, 1982, p. 44).
} 
drew inspiration from the metaphysical framework of Islam as well as from rationality. Other Malay-Muslim sultanates around the region reflects similar background as Malacca in its customs and social outlook. To conclude this section, we can see that although the Malay Archipelago saw different religious forces at play in its pre-colonisation days (Hinduism, Buddhism and Islam), its ethical framework all reflects and understanding of the divine and is closely-related to metaphysical framework.

\section{Section 3: Changes in Ethics in Europe and its impact to Colonial Malaya}

How does the ethical framework in Malaysia changed from a religious-metaphysical framework to a secular one? The answer lies in colonialism. Colonialism in present-day Malaysia started in 1511 with the fall of Malacca at the hands of the Portuguese. The internal political joust for power in the Malaccan court as well as the rampant corruption preceded the invasion (Bakar, 2020, p. 23) and may have facilitated it. Colonialism ended in 1957 with the independence of Peninsular Malaysia from the British and 1963 for Sabah and Sarawak. Not only the ethical framework of the locals underwent changes, but it is to be noted that the European colonial forces also experienced changes in ethical understanding and religious worldview. Over 300 years separated the British and the Portuguese colonization, and the ethical framework that informed and motivated both would have reflected the changes happening in Europe. The Portuguese in 1511 would have their ethical framework still tied to the religious worldview of the Catholics. The Dutch which came in 1641 on the other hand, is Protestant, and would have a different ethics and priorities, not because of different denominations per se, but due to Europe having had Reformation and Enlightenment movement, and this will be elaborated below.

Like Portugal, it was the spice trade that motivated the Dutch to come directly to the Malay Archipelago after its spice access was disrupted. However, there is one major difference between the Portuguese and the Dutch when it came to colonization of this region. Portuguese colonialism was not driven by profit alone, it was also motivated by a desire for Christian missionary activities. Every Portuguese expedition has a Christian priest and churches were set up as a mark of Christian community's presence. Portuguese Malacca was also a base for Jesuit missions with the famed Jesuit priest, St Francis Xavier, organising his missionary activities to other regions in Asia from Malacca (Noonan, 1974).

The same cannot be said about the Dutch. From 1511 to 1641, Europe had experienced a religious upheaval with Martin Luther's Reformation challenging the status quo and many wars were fought between the Catholics and the Protestants, with the Protestants largely located in northern states of the Netherlands and the British Isles. The Netherlands was still trying to gain independence from Spanish rule when it set out for its first expedition to the Malay Archipelago in 1595 via a business expedition which would later form the Dutch East Indies Company (Verenidge Oostindische Compagnie, or VOC) in $1602 .^{3}$ The VOC only employed chaplains in 1605 in West Java but not to actively convert natives like the Jesuits, but to serve VOC's employees, traders, servants and slaves (Macdonald, 2011, p. 117). In fact,

3 The Dutch's colonization in the Malay Archipelago was due to their conflict with Spain which had closed off European markets to the Netherlands and this caused the Dutch to try to buy spices directly from the Malay Archipelago (Macdonald, 2011, p. 113). 
VOC faced difficulty in trying to recruit chaplains to serve at West Java in the beginning because of the long travel and high mortality associated with it (p. 121).

Protestantism differs from Catholicism in its approach to everyday life and new ethical outlook was borne out of this difference in perspective. In contrast to the Catholic church who gave a higher value to the monastic and priestly life, Protestantism rejected such hierarchy in viewing vocation or work. If men are believed to no longer need priests to mediate salvation on their behalf, as he can mediate for himself through his personal commitment to the faith, then, common and ordinary work can have a spiritual value too, not just the monastic life (Taylor, 1989, p. 218). A Christian can still be a faithful servant to God while pursuing a secular calling or job, and this new way of seeing work brought on what Weber called as the Protestant Ethic, an ethic which emphasizes hard work and efficiency (Weber, 2012). Weber credited this hard work ethic to be a factor for the rise of capitalism. Indeed, as we can see in history, it was the Protestant Dutch who founded the first mega corporation in VOC which they used to colonize. They raised capital privately and hired or built ships and staked interests to get profits from the expeditions to the Malay Archipelago (Macdonald, 2011, p. 118). VOC was the first company to ever offered its shares to the public and its trading resulted in the world's first stock exchange in Amsterdam (Petram, 2014). And thus, capitalism began to replace mercantilism in the $17^{\text {th }}$ century and this fueled colonialism even more.

Before we go on to the British, it is important to note the gradual secularization of ethics in the West and this new development in economic framework. Enlightenment thinkers and ideals started to gain ground in Europe propounded by the likes of Voltaire, Montesquieu and Rosseau in $18^{\text {th }}$ century France. The main emphases for these philosophes were to advocate for the primacy of man's reason and freedom from authoritarian governments as well as freedom of religion, the last is understood to mean freedom of the Protestants to freely practice their faith without harassment from the Catholic establishment. It should be noted that the Catholic church is by no means irrational or does not support the use of reason. The Scholastics used rational methods and argumentations to argue or make a case for Christian beliefs. However, this was before the Reformation and the propaganda wars (alongside real wars) fought by both sides to discredit each other. The Enlightenment thinkers criticized the Church for its suppression of Protestants in France and its close relations with the monarchy. After the French Revolution in 1789, the Church's power and influence were reduced. Before the French Revolution, the Church held estates and was influential in universities; in the $18^{\text {th }}$ century, its lands were taken away by the French Republic whereas universities in France were completely secularized, a sharp contrast to the heyday of the University of Paris being the center of Scholastics learning and philosophy during the $12^{\text {th }}$ to $15^{\text {th }}$ century. The Scientific Revolution of the $17^{\text {th }}$ century made the Church with its Aristotelian science looked outdated and it didn't help that most of the pioneers of modern philosophy and science were not Catholics, perpetuating the divide between the Church and science. During the Medieval period under the Holy Roman Empire, the Catholic church saw itself as kingmakers and trailblazers in intellectual discussions, but things were reversed in the $17^{\text {th }}$ and the $18^{\text {th }}$ century where it was emasculated by the secular republican ideals and by modern science. Therefore, the British colonialists that came to Malaya was vastly different from the Portuguese which came in 1511. Our understanding of the history of Malaysia during colonialism tends to lump all the colonizers together without considering the changes that 
happened in Europe. Much have happened there in terms of economic system (mercantilism have been replaced by capitalism), religious rules (Christianity broke into many denominations), science (Scientific and Industrial Revolution) and politics (absolute monarchy to republican ideals or parliamentary monarchy). British rule in Malaya began in 1824 with a treaty signed with the Dutch to settle the partitioning of their colonies.

British colonialism were not just driven by the need to secure raw materials for its Industrial Revolution back home, but also to develop markets to export its products (Sundaram, 1986, p. 37). To this extent, Malaya's riches need more human labor to extricate and this began the mass immigration to Malaya from China and India to supply labors for the mining companies and plantation enterprises (p. 56). Thus, we can see how a change in economic system brought a change in ethical framework, which in the case of Malaysia, mass immigration is driven by the outlook that man is valued merely as labor. The result is, unlike the cosmopolitanism of the pre-colonial states in the Malay Archipelago, immigration during British colonial time was inorganic and structured in such a way where each communities were kept separated in order to fulfill a given economic or administrative role. This made the separate communities evolved differently economically and politically, producing wealth and social inequality among the races whose traces can still be felt today.

British rule also introduced modern administration and political system to Malaya based on the idea of the nation-state. Previously in Europe, political unit of a state where only one nation, or a predominant ethnic group, resides in is a rarity. The Treaty of Westphalia in 1648 cemented the nation-state model as the ideal political unit. Nation-states are a political unit where its people consider itself as part of the same cultural group and that common culture will be the glue that keeps the people together. Thus, the very idea of a nation state was at odds with a place where there are many peoples of different cultures and different historical traditions. The Malays, Indians and Chinese which make up the three main races in Malaysia have neither the same religion nor the same culture nor the same mother tongue. Therefore, post-independence Malaysia faced a challenge in trying to find its common culture which will transcend these divisions.

Colonialism had introduced modernity, albeit a Eurocentric one, to Malaysia and the people of Malaysia were exposed to a European etiquette. Etiquette is a standard that deems what is polite in any given culture, and naturally, this differs from one place to another according to the local customs. Timeliness was also cultivated by the colonialist and this plays an important role in a work culture of a capitalistic society where human labor is expended according to a strict measure of time. This makes timeliness a highly valued form of selfdiscipline because a loss of time means a loss of human labour. This understanding of work culture differs from an agrarian society's understanding of work and time where time is not so strictly measured in hours and minutes but according to the seasons. Pre-colonial Malays was an agrarian society and with colonialism, it could be said that the locals have a new understanding of the importance of keeping time. One wonders if this difference in viewing work is what caused the British and the Dutch to labels the Malays and Javanese as lazy as seen in the accounts of their colonial-administrators (Alatas, 2020, p. 66). ${ }^{4}$

\footnotetext{
${ }^{4}$ Note also that in Europe, the French and Spanish who are slow to catch on the Industrial Revolution and still maintained a non-commercialized agrarian economy
} 
Other forms of Western etiquettes introduced here include proper dining etiquette. A formal dinner would include fork and spoon while eating using hands or on banana leaves which was the custom of the Indians and the Malays was frowned upon. These differences seemed inconsequential, but it did send an impression that local customs were secondary and inferior to Western etiquettes with the formal-informal demarcation. Even more worrisome is when these outwardly etiquettes are taken as the mark of a civilized culture, never mind the fact that civilizations differ from one another and the pre-colonial Malays, Indians and Chinese represented some of the major civilizations of the world with rich intellectual traditions and cultures. Unfortunately, this superficial take on what is considered proper and modern etiquette is still pervasive among Malaysians, a mark of a mind that is still trapped within colonialism. Thus to conclude, we can see that changes in Europe which include secularization, modernization and industrialization have an impact on local culture and the understanding of what is accepted as being civilized. Metaphysical-based ethics has been supplanted by secular ethics.

\section{Section 4: Challenges involving ethical frameworks in post-colonial Malaysia}

Modern Malaysia is similar to the Malaccan Sultanate before that where Islam is taken as the official religion and the Malays as the dominant political force. Post-colonial Malaysia retains some similarities with pre-colonial Malaysia in that both maintain a cosmopolitan and tolerant nature. The different vernacular schools which sprang up during British colonial time were retained and most were assimilated into the national school system and different languages were given constitutional right to be allowed to be taught and learned. Malaysia's colorful history bequeathed her with customs and cultures from India, China, Arabia and Europe and all this seeped into aspects of her citizens' lives producing a very rich and interesting cultural mosaic.

On the ethics side, however, there is still a challenge on what shall be made as the ethical standard. The problem is not so much about the clash between the different religions' ethical framework, such as the Hindu ethical framework clashing with Islamic ethics. On this front, all religions in Malaysia admits of a higher power and a moral order that considers both the spiritual and the physical side of humans. In other words, although the ethical frameworks of each religion have differences, they are similar in that they are all a metaphysical-ethical framework with a belief in the divine. The challenge here is when the clashes are between religious framework and a secular humanistic framework. It is important to note that not all ethical issues brought by a secular humanist framework are or will be at odds with religious ethics. However, on issues that touch both religious rulings and secular law such as on what constitute human rights for example, both ethical frameworks claim their own stake on the issues.

Other challenges are those that come from globalization. In a world that is increasingly made closer together and borderless, issues that happened in other places in the globe can spread to Malaysia in a short amount of time, giving no time for us to ruminate and study on whether the issue, when transplanted onto a Malaysian context, can still be phrased and discussed in the same way as in its place of origin. When issues get imported or exported, it is severed

when the pace of industrialization at other places was already rapid were also called lazy by the British. 
from the original historical and social context of its place of origin although some issues can indeed get adapted and modified to highlight local issues. Clashes in ethical framework among conservatives and progressives when it comes to social and political issues exemplifies this challenge. Like the ethical framework in Ancient Greece which delineates moral virtues according to specific roles and hierarchy in society, pre-colonial Malaysia and the religiously or culturally inspired ethical frameworks have similar understanding where there exist specific sets of virtues according to roles. In a globalized and modernized society, roles no longer seem to be fixed and at times, inversion of roles can happen. This shake-up of the relation between virtues and roles as understood in a religious worldview contributes to the challenges and is what lies at the root of most clashes of worldviews in contemporary Malaysia.

Another challenge that can result from the clash between ethical frameworks is moral relativism, the idea that there is no objective and/or absolute moral order of the universe or framework and what is good and right is not immutable. This brings us back to our early discussion on the evolution of ethics in Ancient Greeks. It could be argued that modern Malaysia, as are other modern nations around the world, are in a similar position like that of Plato and Aristotle during $5^{\text {th }}$ century BC. The ancient Greeks in their encounter with other people saw that others have their own set of beliefs and moral framework, and this led to the Sophists concluding that what is good and evil or right and wrong must be relative and mutable. Thus, what is just in Athens may not be just in Sparta. Similarly, on the same line of argument, what is held good in $11^{\text {th }}$ century Srivijaya can be no longer relevant in $21^{\text {st }}$ century Kuala Lumpur.

Modernization in Malaysian economy managed to bring out many out of poverty and ushered in new economic and education opportunities for Malaysians. However, it is important to take note that the standard of modernization need to be adjusted to fit the cultural and religious values of the locals. If capitalism during the colonial era saw human beings as only labors to be exploited, it is important that capitalism in modern Malaysia is reined in and the economic and social inequality created by colonial-era policies is addressed adequately. If some forms of modern technology and science disregard environmental, religious or ethical issues, then it is incumbent upon Malaysians to figure out a way to adapt these advances to fit the sociocultural context of Malaysia. On the level of thinking, if British colonialism left Malaysians divided and suspicious towards other races, then it is the utmost important task to transcend the differences and look for what is common among each. Every civilization's rise and peak is accompanied by advances in ethics and intellectual culture, and its decline was caused by a break in these two aspects, as Gibbon so aptly show in his account of the decline of the Roman civilization.

\section{Conclusion}

The story of past civilizations shows us what we have inherited in terms of ethical frameworks as well as customs and cultures. We saw that we have always been a cosmopolitan and open society since our early days in the times of the Srivijaya empire and onto the times of Malacca Sultanate. However, these empires, although cosmopolitan, have an overarching ethical framework that is steeped in a metaphysical understanding and this is what bound the society and compelled the people to act in a moral way. In other words, pre-colonial civilizations understand and believe in a moral order of the universe that is not divorced from the 
understanding of the divine. With the introduction of secular humanistic ideals in Malaysia via colonization, and other ethical issues brought here due to globalization, this religious moral order of the universe broke down and a new ethical framework was introduced. Some of these new introductions are good and change Malaysians for the better, while some others caused deep clashes with the religious moral worldview or accepted local customs. The challenge today is to navigate these clashes and find a way to come to agreement on what constitutes right and wrong or good and evil. Any solutions posed must take into consideration the colorful heritage and the struggle Malaysians have surmounted together in the early years of the formation of this nation. It will be a tough and challenging effort, but the rich history of this region will be there to serve as a guide.

\section{References}

Abdullah, A. H., \& Fathil, F. (2021). The Concept of Al-Ta'ayush in Islamic Cosmopolitanism: From Medina to Istanbul and Malacca. Islāmiyyāt, 43(1), 163-171.

Adkins, A. (1972). Moral Values and Political Behaviours in Ancient Greece: From Homer to the End of the Fifth Century. London: Chatto \& Windus.

Al-Attas, S. M. (1969). Preliminary Statement on the Islamization of the Malay-Indonesian Archipelago. Kuala Lumpur: Dewan Bahasa dan Pustaka.

Al-Attas, S. M. (1972). Islam dalam Sejarah dan Kebudayaan Melayu . Petaling Jaya: ABIM.

Al-Attas, S. M. (2011). Historical Fact and Fiction. Kuala Lumpur: Penerbit UTM.

Al-Attas, S. M. (2015). On Justice and the Nature of Man. Kuala Lumpur: IBFIIM.

Andaya, B. W., \& Andaya, L. Y. (1982). A History of Malaysia . London: Macmillan Publishing.

Bakar, O. (2020). Portugal's Conquest of Malacca and Spice Monopoly. In O. Bakar, A. M. Merican, \& W. A. Mamat, Colonialism in the Malay Archipelago: Civilisational Encounters (pp. 1-32). Kuala Lumpur: ISTAC-IIUM Publications.

Barney, R. (2012). The Sophistic Movements. In M. L. Gill, \& P. Pellegrin, Companion to Ancient Philosophy (pp. 77-97). New Jersey: Blackwell Publishing.

Battutah, I. (2002). The Travels of Ibn Battutah, ed. by Tim Mackintosh-Smith. London: Picador.

Chia, S., \& Majid, Z. (2002). The Conservation and Preservation of Perak Man from Gua Gunung Runtuh Site in Lenggong, Perak, Malaysia. The International Symposium on the Conservation and Preservation of Java Man Site (Indonesia) and Peking Man Site (China).

Coedès, G. (1975). The Indianized States of Southeast Asia, trans. by Susan Brown Cowing. Canberra: Australian National University Press.

Feyerabend, P. (1987). Reason, Xenophanes and the Homeric Gods. The Kenyon Review, 9(4), 12-22.

Husain, W. A., Ngah, A. C., \& Din, M. A. (2018). Kedaulatan dan Hukum Kanun Melaka. Jurnal Undang-undang dan Masyarakat, 22, 61-73.

Khaw, N. R., Zainun, N., \& Saidin, M. (2017). Kedah Tua: Satu Cerakinan Sumber India. Journal Arkeologi Malaysia, 30, 11-19.

Macdonald, J. (2011). Dutch East India Company: Strict Protestantism and Intolerance. In J. Temmerman, Religious Radicalism (pp. 111-128). Brussels: ASP.

Macintyre, A. (2002). A Short History of Ethics: A History of Moral Philosophy from the Homeric Age to the 20th Century. New York: Routledge Classics.

Majul, C. A. (2010). An Historical Background on the Coming and Spread of Islam and Christianity in Southeast Asia. Asian Studies Retrospective, 1(46), 34-47. 
Merican, A. M. (2020). Representations of Colonialism in Colonialism in the Malay Archipelago. In O. Bakar, A. M. Merican, \& W. A. Mamat, Colonialism in the Malay Archipelago: Civilisational Encounters (pp. 33-48). Kuala Lumpur: ISTAC-IIUM Publications.

Noonan, L. A. (1974). The First Jesuit Mission in Malacca: A Study of the Use of Portuguese Trading Centre as a Base for Christian Missionary Expansion during the years 1545 to 1552. Lisbon: Centro de Estudos Historicos Ultramarinos.

Oxford English Dictionary. (1989). Retrieved from Oxford English Dictionary: https://www.oed.com/oed2/00151262

Petram, L. (2014). The World's First Stock Exchange, trans. by Lynne Richards. New York: Columbia University Press.

Rahman, P. N., \& Ahmad, Z. (2017). Hubungan Simbolisme dan Spiritualisme Dewa-Raja dalam Kesusasteraan Melayu Klasik. Kemanusiaan, 24(2), 123-139.

Ramli, Z. (2014). Pembentukan Kerajaan Awal di Nusantara abad 1 hingga 5 Masihi Berdasarkan Sumber Bertulis dan Data Arkeologi. Jurnal Arkeologi Malaysia, 27, 85-104.

Scheidel, W. (2008). The Comparative Economics of Slavery in the Greco-Roman World. In E. del Lago, \& C. Kastari, Slave Systems: Ancient and Modern (pp. 105-126). Cambridge: Cambridge University Press.

Sundaram, J. K. (1986). A Question of Class: Capital, the State and Uneven Development in Malaya. Singapore: Oxford University Press.

Taylor, C. (1989). Sources of the Self. Cambridge: Cambridge University Press.

Weber, M. (2012). The Protestant Ethic and the Spirit of Capitalism. London: Routledge Classics.

Winstedt, R. (1935). A History of Malaya. JMBRAS, 13(121), iii-270. 